\title{
Contribuição ao estudo da correlação entre as alternativas éticas e os modelos bioéticos e sua aplicabilidade na reflexão da relação profissional-paciente
}

\author{
A study contribution to the correlation between ethical \\ alternatives and bioethical models and its applicability \\ on the professional-patient relationship
}

Fernando Jorge Maia Abraão

\begin{abstract}
Abraão FJM. Contribuição ao estudo da correlação entre as alternativas éticas e os modelos bioéticos e sua aplicabilidade na reflexão da relação profissional-paciente [Resumo]. Saúde, Ética \& Justiça, São Paulo. 2003;8(1/2):62-3.

RESUMO: Muitos sistemas éticos foram propostos no correr da História da Filosofia. Dentre estes encontraremos os seres humanos, ora como origem dos conceitos e normas de conduta, ora como meio para o alcance de um ou mais objetivos específicos, ora como fim a ser satisfeito. Tratando das ciências da vida, não se escapa deste quadro geral. A Bioética se desenvolve sob a guarda e os princípios das alternativas genericamente citadas acima. A relação existente entre a Bioética e aquelas alternativas (o homem como origem, meio ou fim das condutas), o questionamento a respeito do modo de interpretar a vida e viver e a sua aplicabilidade à prática clínica são assuntos abordados neste trabalho. Conclui-se que a Alternativa Ética Hierárquica relacionada ao Modelo Bioético Personalista Reformado apresenta relevante contribuição para a solução dos dilemas de todos os tempos, inclusive aqueles enfrentados na clínica diária.
\end{abstract}

DESCRITORES: Ética profissional. Bioética. Relações dentista-paciente. Odontologia legal.

Dissertação de mestrado apresentada a Faculdade de Odontologia da Universidade de São Paulo, defendida em 20/01/2003.

Orientador: Dalton Luís de Paula Ramos. 
Abraão FJM. Contribuição ao estudo da correlação entre as alternativas éticas e os modelos bioéticos. [Resumo].

Abraão FJM. A study contribution to the correlation between ethical alternatives and bioethical models and its applicability on the professional-patient relationship [Abstract]. Saúde, Ética \& Justiça, São Paulo. 2003;8(1/2):62-3.

ABSTRACTS: Beyond all the philosophy systems, men can be found related with concepts and norms in three generic different ways (alternatives): as its origin, as its medium, or, finally, as its aim. Dealing with life sciences, the same understanding is found. Bioethics development occurs under the same principles and alternatives mentioned above. A few questions rise from it: What is the relationship beyond ethical alternatives and the science of Bioethics and its models? Would that be a better understanding way of (1) the interpretation of life and its requirements and (2) living? How can this knowledge be applied to the professional-patient relationship? This work points up to the Hierarchic Ethical Alternative, witch is related to the Reformed Personal Bioethical Model. Both of them are Bible based systems and give the best answers men can achieve to every time dilemmas, including those faced on daily clinic .

KEY WORDS: Ethics, professional. Bioethics. Dentist-patient relations. Forensic dentistry. 